\title{
Criptógamos do Parque Estadual das Fontes do Ipiranga, São Paulo, SP. Pteridophyta: 9. Grammitidaceae e 16. Polypodiaceae
}

\author{
Jefferson Prado ${ }^{1,4}$, Regina Yoshie Hirai $^{2}$ e Pedro Bond Schwartsburd ${ }^{3}$
}

Recebido: 29.04.2010; aceito: 22.07 .2010

\begin{abstract}
Cryptogams of "Parque Estadual das Fontes do Ipiranga", São Paulo, SP. Pteridophyta: 9. Grammitidaceae e 16. Polypodiaceae). In this work we present a floristic survey of the fern families Grammitidaceae and Polypodiaceae occurring in "Parque Estadual das Fontes do Ipiranga" (PEFI), located in São Paulo, SP, Southeastern of Brazil. Grammitidaceae is represented in the area by only one genus and one species: Micropolypodium achilleifolium (Kaulf.) Labiak \& F.B. Matos, while Polypodiaceae is represented by 15 species, classified into six genera: Campyloneurum (C. nitidum (Kaulf.) C. Presl), Microgramma (M. percussa (Cav.) de la Sota, M. squamulosa (Kaulf.) de la Sota, and M. vacciniifolia (Langsd. \& Fisch.) Copel.), Pecluma (P. paradisae (Langsd. \& Fisch.) M.G. Price, P. truncorum (Lind.) M.G. Price, and P. singeri (de la Sota) M.G. Price.), Phlebodium (P. areolatum), Pleopeltis (P. astrolepis, P. hirsutissima, and P. pleopeltifolia), and Serpocaulon (S. catharinae, S. meniscifolium, S. sehnemii, and S. vacillans). We also present keys to identify the genera and the species, as well as description, geographical distribution, comments, and illustrations for some taxa.
\end{abstract}

Key words: Atlantic Forest, grammitid ferns, polygrammoid ferns, taxonomy

RESUMO - (Criptógamos do Parque Estadual das Fontes do Ipiranga, São Paulo, SP. Pteridophyta: 9. Grammitidaceae e 16. Polypodiaceae). Neste trabalho são apresentados os dados referentes ao levantamento florístico das famílias Grammitidaceae e Polypodiaceae, no Parque Estadual das Fontes do Ipiranga (PEFI). Grammitidaceae está representada na área por apenas um gênero e uma espécie: Micropolypodium achilleifolium (Kaulf.) Labiak \& F.B. Matos, enquanto que em Polypodiaceae há 15 espécies, enquadradas em seis gêneros: Campyloneurum (C. nitidum (Kaulf.) C. Presl, Microgramma (M. percussa (Cav.) de la Sota, M. squamulosa (Kaulf.) de la Sota e M. vacciniifolia (Langsd. \& Fisch.) Copel.), Pecluma (P. paradisae (Langsd. \& Fisch.) M.G. Price, P. truncorum (Lind.) M.G. Price e P. singeri (de la Sota) M.G. Price), Phlebodium (P. areolatum), Pleopeltis (P. astrolepis, P. hirsutissima e P. pleopeltifolia) e Serpocaulon (S. catharinae, S. meniscifolium, S. sehnemii e $S$. vacillans). São apresentadas chaves para identificação dos gêneros e espécies, bem como descrições, distribuição geográfica, comentários e ilustrações de alguns táxons.

Palavras-chave: Floresta Atlântica, samambaias gramitidóides, samambaias poligramóides, taxonomia

\section{Introdução}

O presente trabalho é uma continuação do levantamento florístico das samambaias e licófitas do Parque Estadual das Fontes do Ipiranga (PEFI) iniciado por Hoehne (1941) e, prosseguido posteriormente, pelos trabalhos de Prado (2004a, b, c, d, e, f, g, 2006a, b) e Prado \& Hirai (2008).

No atual sistema de classificação (Smith et al. 2006b, 2008), as gramitidóides são consideradas um grupo monofilético dentro da família Polypodiaceae.
Até pouco tempo atrás, as gramitidóides eram reconhecidas como uma família a parte Grammitidaceae (C. Presl) Ching, por exemplo, em Parris (1986) e Moran \& Riba (1995), e anteriormente, já haviam sido tratadas em Polypodiaceae s.l. por Baker (1870), Copeland (1947) e Tryon \& Tryon (1982). Somente com os estudos filogenéticos (Smith et al. 2006b, 2008) foi possível comprovar que Polypodiaceae s.s., como frequentemente reconhecida, era um grupo parafilético, uma vez que excluía Grammitidaceae.

1. Instituto de Botânica, Herbário SP, Caixa Postal 3005, 01031-970 São Paulo, SP, Brasil

2. Instituto de Botânica, Curso de Pós-Graduação em Biodiversidade Vegetal e Meio Ambiente, Caixa Postal 3005, 01031-970 São Paulo, SP, Brasil

3. Universidade de São Paulo, Curso de Pós-Graduação em Botânica, Rua do Matão 277, 05508-090 São Paulo, SP, Brasil

4. Autor para correspondência:.jprado.01@uol.com.br 
Dos trabalhos mais recentes e relevantes com as gramitidóides no Brasil, destaca-se a revisão realizada por Labiak \& Prado (2003, 2005a, b, c), na qual são apresentados os tratamentos taxonômicos de oito gêneros (Ceradenia, Cochlidium, Grammitis, Lellingeria, Melpomene, Micropolypodium, Terpsichore e Zygophlebia) e 55 espécies.

Para Polypodiaceae no Brasil, há apenas alguns trabalhos regionais para a família, por exemplo, Rolim \& Salino (2008) que estudaram as espécies no Parque Estadual do Itacolomi, Minas Gerais, no qual foram encontrados 15 gêneros e 28 espécies, sendo que desses, sete gêneros e 13 espécies pertencem às gramitidóides. Assis \& Labiak (2009) realizaram o levantamento das espécies da borda oeste do Pantanal sul-matogrossense e encontraram 14 espécies, pertencentes aos gêneros Pecluma (quatro espécies), Pleopeltis (três espécies), Campyloneurum, Microgramma e Phlebodium (duas espécies cada) e Serpocaulon (uma espécie). Arantes et al. (2010), para a Estação Ecológica do Panga em Uberlândia, também em Minas Gerais, encontraram sete espécies distribuídas em quatro gêneros (Campyloneurum, Microgramma, Pecluma e Phlebodium). Nenhuma gramitidóide foi encontrada nessas duas últimas áreas.

Em relação a trabalhos de revisões em Polypodiaceae no Brasil há apenas o trabalho de Labiak \& Prado (2008) que abordaram as espécies do sul e sudeste do país referentes a Serpocaulon, um gênero recentemente segregado de Polypodium s.l. por Smith et al. (2006a).

\section{Material e métodos}

O material para este trabalho foi coletado de acordo com as técnicas descritas em Fidalgo \& Bononi (1984) e encontra-se depositado nos Herbários do Instituto de Botânica (SP) e do Departamento de Botânica da Universidade de São Paulo (SPF).

Os dados sobre a caracterização e localização do Parque Estadual das Fontes do Ipiranga (PEFI), bem como o planejamento desta flora, foram apresentados em Melhem et al. (1981) e Milanez et al. (1990).

Neste trabalho são apresentadas as Grammitidaceae e Polypodiaceae seguindo-se a circunscrição de famílias, utilizada por Moran \& Riba (1995), para a Flora Mesoamericana, adotada desde o início das publicações da flora de samambaias do PEFI (Prado 2004a). Optou-se por apresentar estas duas famílias em um mesmo artigo, porque de acordo com a classificação mais recente de Smith et al. (2006b, 2008), seus membros pertencem a uma única família, denominada Polypodiaceae.

O número que antecede o nome das famílias, no título deste trabalho corresponde à numeração das famílias apresentadas em Prado (2004a). A chave para todas as famílias encontradas na área do PEFI, incluindo Grammitidaceae e Polypodiaceae, também foi publicada nesse mesmo artigo.

Os táxons estudados estão apresentados em ordem alfabética de gêneros e espécies. A abreviação dos nomes dos autores de táxons está de acordo com Pichi-Sermolli (1996).

A nomenclatura para o padrão de nervuras dos gêneros se baseia em de la Sota (1960) e Lellinger (2002). Para a denominação das escamas unisseriadas ("proscales"), filiformes, geralmente adpressas e castanho-avermelhadas, foi utilizado o mesmo conceito de Moran et al. (2009).

A circunscrição do gênero Micropolypodium está apresentada de acordo com os conceitos mais recentes de Ranker et al. (2004) e Labiak \& Matos (2007).

São apresentadas ilustrações apenas das espécies de Pecluma, por se tratar do grupo com maior grau de dificuldade para identificação. Além disso, para as outras espécies de Polypodiaceae (Campyloneurum, Microgramma, Phlebodium e Pleopeltis), bem como de Grammitidaceae (Micropolypodium), já existem ilustrações disponíveis na literatura, uma vez que elas são espécies bastante comuns e de fácil identificação. Para Serpocaulon há a revisão recentemente publicada por Labiak \& Prado (2008), que apresentaram ilustrações das mesmas espécies tratadas nesta flora.

Para a visualização e ilustração das nervuras de Pecluma singeri foi feito o clareamento (diafanização) da lâmina foliar com hipoclorito de sódio e posteriormente foi corada com safrablau $1 \%$.

\section{Resultados e Discussão}

No presente levantamento foi encontrada na área do PEFI uma única espécie de Micropolypodium, pertencente à Grammitidaceae e 15 espécies de Polypodiaceae, distribuídas em seis gêneros.

\section{Grammitidaceae}

Plantas terrestres, rupícolas ou geralmente epífitas; caule longo a curto-reptante ou subereto, geralmente não ramificado, solenostélico a dictiostélico, 
com escamas. Frondes monomorfas, eretas, arqueadas ou pêndulas, geralmente sem escamas; pecíolo na maioria $<2 \mathrm{~mm}$ de diâmetro, geralmente cilíndrico, articulado ou não articulado, com 1 ou 2 feixes vasculares; lâmina inteira a geralmente pinatífida ou 1-pinada, raramente 2-pinada, glabra ou geralmente com tricomas castanho-amarelados ou castanho-escuros, unicelulares a pluricelulares, principalmente sobre o pecíolo e a raque, sem canaletas adaxialmente; nervuras livres a anastomosadas em padrões simples; com ou sem hidatódios, às vezes ocultos por substância esbranquiçada adaxialmente. Soros geralmente arredondados a oblongos; indúsio ausente; paráfises ausentes ou presentes, glandulosas ou setosas; pedicelo do esporângio com 1 fileira de células; esporos triletes, clorofilados, com superfície geralmente papilosa.

A família apresenta cerca de 15 gêneros com aproximadamente 500 espécies, ocorrendo nos trópicos e subtrópicos, sendo que quase $50 \%$ das espécies ocorrem na região neotropical (Smith 1995). No Brasil ocorrem 56 espécies e um híbrido, distribuídas em oito gêneros (Labiak \& Prado 2003, 2005a, b, c, Labiak \& Matos 2007, Labiak \& Condack 2008).

\section{Micropolypodium Hayata}

Plantas epífitas ou raramente rupícolas e terrestres. Caule dorsiventral ou radial, curtoreptante a decumbente, com escamas amareladas a castanho-claras, geralmente brilhantes, não clatradas, margens inteiras ou ligeiramente irregulares, ou com projeções setiformes, hialinas ou castanho-avermelhadas, às vezes com projeções glanduliformes, filopódios ausentes. Frondes monomorfas, cespitosas; pecíolo curto a longo, ou ausente, contínuo com o caule; lâmina pinatífida, pinatissecta, 1-pinado-pinatissecta ou 1-pinado-pinatífida, linear; segmentos gibosos ou não no lado acroscópico; nervuras simples a pinadas, geralmente visíveis; hidatódios presentes, geralmente 1, 2 ou vários por segmentos, elípticos a claviformes; indumento presente formado por setas castanhas a castanho-avermelhadas e tricomas hialinos a castanho-avermelhados, simples ou ramificados, septados, geralmente glandulares no ápice, indumento geralmente sobre o pecíolo, raque, costa e lâmina. Soros arredondados, superficiais, um ou vários por segmento, localizados na base das nervuras, ou na extremidade da nervura secundária acroscópica; paráfises ausentes; esporângios glabros; esporos com superfície verrucosa.

Micropolypodium é um gênero que foi descrito para a Ásia, entretanto a maioria das espécies ocorre na região neotropical. Segundo Smith (1992), há cerca de 30 espécies. Este gênero sofreu há pouco tempo uma alteração na sua circunscrição em decorrência do trabalho de filogenia molecular de Ranker et al. (2004), bem como pela descoberta de um híbrido por Labiak $\&$ Matos (2007) (Micropolypodium $\times$ bradei Labiak \& F.B. Matos, cujos parentais são Micropolypodium setosum (Kaulf.) A.R.Sm.) e Terpsichore achilleifolia (Kaulf.) A.R.Sm. Na filogenia de gramitidóides, $T$. achilleifolia e T. longisetosa (Hook.) A.R. Sm. (o grupo cinco, de Smith 1993) formam, juntamente com as espécies neotropicais de Micropolypodium, um grupo monofilético, consequentemente essas duas espécies de Terpsichore foram transferidas por Labiak \& Matos (2007) para Micropolypodium.

$\mathrm{Na}$ área do PEFI ocorre apenas Micropolypodium achilleifolium.

Micropolypodium achilleifolium (Kaulf.) Labiak \& F.B. Matos, Brittonia 59(2): 184. $2007 \equiv$ Polypodium achilleifolium Kaulf., Enum. Filic.: 116. 1824.

Plantas epífitas. Caule horizontal, curtoreptante, ca. 0,1 cm diâm., com escamas em um tufo aglomerado no ápice do caule, 1,5-2,0 × 0,3$0,4 \mathrm{~mm}$, amareladas, lanceoladas, base truncada ou levemente cordada, ápice atenuado, margens geralmente inteiras. Frondes eretas a levemente arqueadas, crescimento determinado, 5,0-11,5 × 1,92,6 cm; pecíolo curto, 0,5-1,0 cm compr., castanho, não alado; lâmina pinatissecta, às vezes pinada na base, estreitando-se gradativamente para a base e para o ápice, cartácea; costa visível e levemente esclerificada abaxialmente, não visível e imersa no tecido laminar adaxialmente; segmentos geralmente ascendentes, formando um ângulo de $30^{\circ}-60^{\circ}$ com a costa, 16-27 pares, espaçados, alternos, não gibosos, simétricos, 10,0-14,0 mm $\times$ 2,0-3,0 mm, lineares, pinatissectos, levemente decorrentes na base, ápice arrredondado, margens planas ou levemente revolutas, sem uma camada de células hialinas; nervuras pinadas, não visíveis, imersas no tecido laminar, vários hidatódios por segmento, elípticos ou arredondados; indumento presente formado de setas castanho-avermelhadas, 0,6-1,0 mm compr., sobre o pecíolo, raque e o tecido laminar (em ambas as superfícies da lâmina) e 
tricomas hialinos, levemente castanho-avermelhados, geralmente ramificados, ca. 0,2 mm compr., sobre a costa, nervuras e o tecido laminar (principalmente abaxialmente). Soros arredondados ou elípticos, 1,11,5 mm diâm., localizados no ápice das nervuras.

Material examinado: 19-IX-1938, O. Handro s.n. (SP44458, SPF93829).

Distribuição geográfica: Endêmica do leste do Brasil - Bahia, Minas Gerais, Espírito Santo, Rio de Janeiro, São Paulo, Paraná, Santa Catarina e Rio Grande do Sul.

Micropolypodium achilleifolium pode ser facilmente reconhecido por apresentar crescimento determinado, pela lâmina pinatissecta, revestida por setas, castanho-avermelhadas, distribuídas por todo o tecido laminar em ambas as superfícies da lâmina, bem como pelas escamas do caule amareladas, com margens geralmente inteiras.

Esta espécie não foi encontrada recentemente na área do PEFI, muito provavelmente ela não ocorre mais na área do Parque, uma vez que é uma espécie sensível à poluição urbana.

Polypodiaceae

Plantas geralmente epífitas, às vezes terrestres ou rupícolas. Caule geralmente dorsiventral, curto ou longo-reptante, com 2 fileiras de frondes na superfície dorsal, com escamas, estas geralmente peltadas ou basifixas, clatradas ou não clatradas. Frondes estéreis e férteis monomorfas a dimorfas, articuladas aos filopódios curtos; lâmina geralmente inteira, pinatissecta ou 1-pinada, raramente 1-pinadopinatífida a 3-pinada ou subdicotomicamente bifurcada; segmentos lineares, lanceolados ou falcados, às vezes auriculados na base; nervuras livres ou anastomosadas (gonioflebóide ou citoflebóide), com ou sem vênulas inclusas nas aréolas. Soros geralmente arredondados, alongados ou lineares, sem indúsio; pedicelo dos esporângios com 2 ou 3 fileiras de células, ânulo vertical e interrompido pelo pedicelo; esporos monoletes, reniformes, amarelados, não clorofilados, com superfície verrugosa, tuberculada, rugulada ou levemente verrugosa.

Estafamíliaécosmopolita,comaproximadamente 40 gêneros e 600 espécies, ocorre principalmente nas regiões tropicais (Moran 1995a). De acordo com a atual classificação desta família, publicada por Smith et al. (2006b, 2008), as samambaias gramitidoídes (anteriormente segregadas em Grammitidaceae), as loxogramóides (antes em uma família à parte Loxogramaceae), as platicerióides (Platyceriaceae), etc., pertencem às Polypodiaceae. Com esta junção dos grupos atualmente pertencem à Polypodiaceae cerca de 56 gêneros e 1200 espécies.

Chave para os gêneros de Polypodiaceae

1. Caule com escamas basifixas; lâmina pectinada (i.e., pinatissecta com segmentos lineares, estreitos e paralelos entre si); nervuras livres Pecluma

1. Caule com escamas peltadas; lâmina inteira, pinatífida, pinatissecta, subdicotomicamente dividida, ou 1-pinada; nervuras anastomosadas

2. Nervuras anastomosadas do tipo gonioflebóide (regularmente anastomosadas e aréolas com apenas uma única vênula livre inclusa) Serpocaulon

2. Nervuras anastomosadas do tipo citoflebóide (regularmente anastomosadas e aréolas com duas ou mais vênulas livres inclusas) ou irregularmente anastomosadas (aréolas com uma a várias vênulas livres inclusas ou sem vênulas)

3. Nervuras regularmente anastomosadas do tipo citoflebóide Campyloneurum

3. Nervuras irregularmente anastomosadas

4. Escamas do caule subclatradas a clatradas; soros imaturos protegidos por escamas Pleopeltis

4. Escamas do caule não clatradas; soros imaturos não protegidos por escamas

5. Lâmina inteira; soros com paráfises Microgramma

5. Lâmina pinatissecta; soros sem paráfises Phlebodium

\section{Campyloneurum C. Presl}

Plantas epífitas, terrestres, hemiepífitas ou rupícolas. Caule curto a longo-reptante, simples ou ramificado; com escamas peltadas, geralmente clatradas, concolores, castanhas, atropurpúreas, ferrugíneas, castanho-amareladas ou paleáceas. Frondes monomorfas; pecíolo geralmente presente 
e articulado aos filopódios; lâmina inteira ou raramente 1-pinada, lineares a elípticas, atenuadas na base e no ápice, margens inteiras, glabra, glabescente ou pubérula com tricomas simples ou ramificados, geralmente inconspícuos ou com escamas sobre a costa; costa proeminente; nervuras anastomosadas do tipo citoflebóide, nervuras primárias visíveis formando ângulos de divergência com a costa de $45^{\circ}-75^{\circ}$, paralelas, fusionandose entre as nervuras opostas e formando aréolas primárias com 1-6 nervuras simples ou divididas, geralmente excurrentes, livres ou anastomosadas, neste caso formando aréolas secundárias, ápice das nervuras livres com hidatódios. Soros arredondados, localizados nas nervuras inclusas na porção mediana ou apical, raramente na união de 2 nervuras, em 2-4(-6) fileiras entre as nervuras primárias; paráfises raramente presentes, simples ou ramificadas.

Campyloneurum é um gênero que foi segregado de Polypodium s.l. e apresenta cerca de 50 espécies neotropicais. É caracterizada pela presença de frondes monomorfas, simples (somente duas espécies na América do Sul têm frondes 1-pinada); soros geralmente sem paráfises, localizados nas extremidades das vênulas livres inclusas e escamas do caule clatradas e glabras (Mickel \& Smith 2004).

$\mathrm{Na}$ área do PEFI este gênero está representado também por uma única espécie: Campyloneurum nitidum.

Campyloneurum nitidum (Kaulf.) C. Presl, Tent. Pterid.: 190. 1836 E Polypodium nitidum Kaulf. Enum. Filic.: 92. 1824.

Plantas epífitas. Caule horizontal, curto reptante, 0,5-0,8 cm diâm., revestido no ápice por escamas não clatradas, $1,0-2,8 \times 0,8-2,2 \mathrm{~mm}$, castanhas, orbiculares, margens inteiras. Frondes $26,0-63,0 \times$ 2,2-4,8 cm; pecíolo ausente ou muito curto, até 0,5 $\mathrm{cm} \times$ ca. 3,0 mm, amarelado, fortemente anguloso; lâmina cartácea a coriácea, lanceolada, longamente atenuada para a base e menos para o ápice, margens inteiras, às vezes levemente crenadas, com escamas unisseriadas, filiformes, adpressas, castanhoavermelhadas, abaxialmente sobre as nervuras e tecido laminar, ca. 0,1 mm compr., mais escassas adaxialmente; nervuras anastomosadas, partindo da costa em um ângulo de aproximadamente $75^{\circ}$, aréolas em 4-7 fileiras entre a costa e a margem da lâmina, com uma ou, na maioria das vezes, duas, ou até três vênulas livres inclusas, férteis, por vezes uma terceira vênula estéril cruza a aréola dividindo-a ao meio. Soros arredondados, localizados no ápice das vênulas inclusas, 4-7 séries em cada lado da costa. Material examinado: 18-IX-1928, F.C. Hoehne s.n. (SP26512); VIII-1958, sem coletor s.n. (SP154341); 13-VII-1960, G. Eiten et al. 2086 (SP); 10-X-1973, O. Handro 2231 (SPF); 3-VI-1974, O. Handro 2260 (SPF); 8-VIII-1979, A. Custodio Filho 127 (SP); 6-X-2003, J. Prado \& D.M. Vital 1437 (SP); 20-XII2005, J. Prado \& G.B. Silva 1618 (SP).

Distribuição geográfica: Argentina, Paraguai, Uruguai e Brasil - Bahia, Minas Gerais, Espírito Santo, Rio de Janeiro, São Paulo, Paraná, Santa Catarina e Rio Grande do Sul.

Campyloneurum nitidum é facilmente distinguido das outras espécies do gênero por apresentar um caule curto-reptante, robusto ( $0,5-0,8 \mathrm{~cm}$ diâm.), com frondes de $26,0-63,0 \times 2,2-4,8 \mathrm{~cm}$ e pecíolo ausente ou muito curto (até $0,5 \mathrm{~cm}$ compr.).

Esta espécie foi equivocadamente tratada em trabalhos recentes de flora como sendo Campyloneurum major (Hieron. ex Hicken) Lellinger (Labiak \& Prado 1998, Boldrin \& Prado 2007, Nóbrega \& Prado 2008).

$\mathrm{Na}$ área do PEFI esta espécie ocorre como epífita sobre fanerógamas ou samambaias arborescentes (Cyatheaceae).

\section{Microgramma C. Pres1}

Plantas epífitas ou raramenterupícolas e terrestres. Caule horizontal, longo-reptante, geralmente ramificado, com escamas peltadas, não clatradas, aciculares a lanceoladas, imbricadas. Frondes estéreis e férteis monomorfas a conspicuamente dimorfas (as férteis mais estreitas e longas do que as estéreis), articuladas, filopódio obsoleto ou presente; pecíolo curto a longo; lâmina cartácea a subcoriácea, inteira, oval a elíptica ou oblonga, glabra ou com escamas filamentosas ou arredondadas; nervuras visíveis ou ocultas, irregularmente anastomosadas, aréolas com uma, duas ou nenhuma vênula inclusa. Soros arredondados ou oblongos, localizados no ápice da(s) vênula(s) inclusa(s), em 1 fileira, entre a costa e a margem, não protegidos por escamas quando imaturos; paráfises presentes, estas sendo escamas filiformes ou escamas ramificadas com ápices filiformes; esporângios glabros.

Microgramma também é um gênero que foi segregado de Polypodium s.l. e compreende aproximadamente 30 espécies no neotrópico com apenas uma ou duas espécies ocorrendo na África. O gênero é distinguido por apresentar frondes dimorfas 
a monomorfas, nervuras anastomosadas, escamas do caule peltadas, não clatradas, soros geralmente unisseriados ou bisseriados, com paráfises escamosas (Mickel \& Smith 2004, Salino et al. 2008).

\section{Chave para as espécies de Microgramma}

1. Frondes monomorfas a levemente dimorfas, 22,533,5 cm compr.; lâmina estéril lanceolada; escamas do caule com margens inteiras a levemente denticuladas, ápice agudo ................. M. percussa

1. Frondes conspicuamente dimorfas, 0,9-16,7 cm compr.; lâmina estéril oval a elíptica ou elíptica a lanceolada; escamas do caule com margens ciliadas e ápice agudo ou margens inteiras a denticuladas e ápice filiforme

2. Escamas do caule com margens ciliadas e ápice agudo; escamas da lâmina geralmente ovais; soros localizados em 2 ou 3 vênulas livres inclusas nas aréolas ................. M. squamulosa

2. Escamas do caule com margens inteiras a denticuladas (muito raramente com cílios esparsos) e ápice filiforme; escamas da lâmina aracnóides; soros localizados em 1 única vênula livre inclusa nas aréolas

M. vacciniifolia

Microgramma percussa (Cav.) de la Sota, Physis (Buenos Aires), Secc. C, 44(106): 28. $1986 \equiv$ Polypodium percussum Cav., Descr. pl.: 243. 1802.

Plantas epífitas. Caule 1,5-2,0 cm diâm., revestido por escamas, 3,3-5,5 × 1,0-1,6 mm, castanhoclaras, às vezes castanho-escuras, lanceoladas a oval-lineares, base arredondada, ápice agudo a levemente atenuado, margens inteiras a levemente denticuladas. Frondes monomorfas a levemente dimorfas, 22,5-33,5 × 1,1-2,8 cm; pecíolo longo, 3,7-6,5 $\times$ ca. $0,1 \mathrm{~cm}$, castanho-claro; lâmina fértil e estéril coriáceas, lâmina fértil, linear-lanceolada, às vezes lanceolada, base abruptamente atenuada, ápice atenuado, nas proximidades da costa revestida por escamas, lanceoladas, margens ciliadas, tecido laminar também revestido por escamas, geralmente arredondadas, margens conspicuamente ciliadas; lâmina estéril lanceolada, base abruptamente atenuada, ápice atenuado, com escamas semelhantes às da lâmina fértil; nervuras imersas no tecido laminar, anastomosadas, com 1 a várias vênulas livres inclusas ou sem vênulas, esparsamente distribuídas nas aréolas, visíveis no lado adaxial. Soros arredondados a oblongos, localizados medianamente entre a costa e a margem da lâmina, formando adaxialmente na lâmina uma cicatriz em seu ponto de inserção; paráfises numerosas, filiformes, recobrindo completamente os esporângios.

Material examinado: 15-VIII-1939, O. Handro s.n. (SP44456).

Distribuição geográfica: sul do México e Panamá, Colômbia e Guianas, sul da Bolívia e Brasil Amapá, Pará, Roraima, Amazonas, Acre, Rondônia, Maranhão, Tocantins, Ceará, Rio Grande do Norte, Paraíba, Pernambuco, Alagoas, Bahia, Mato Grosso, Goiás, Distrito Federal, Mato Grosso do Sul, Minas Gerais, Espírito Santo, Rio de Janeiro, São Paulo, Paraná, Santa Catarina e Rio Grande do Sul.

Segundo Mickel \& Smith (2004), Microgramma percussa apresenta soros com paráfises numerosas e filiformes, escamas da lâmina pequenas e arredondadas, lâmina coriácea, geralmente com ápice longo-acuminado. Além disso, as nervuras nessa espécie são geralmente visíveis nas frondes secas adaxialmente, contrastando com a cor da lâmina.

Microgramma squamulosa (Kaulf.) de la Sota, Opera Lilloana 5: 59, fig. 2, 3, 6, 7. 1961 三 Polypodium squamulosum Kaulf., Enum. Filic.: 89. 1824.

Plantas epífitas. Caule 2,0-4,0 mm diâm., coberto por escamas, 4,0-5,5 $\times 0,9-1,4 \mathrm{~mm}$, castanhoescuras ou castanho-claras, oval-lanceoladas, base auriculada, ápice agudo, margens ciliadas. Frondes conspicuamente dimorfas, fronde estéril 4,8-12,8 $\times$ 1,3-1,9 cm, fronde fértil 7,5-16,7 × 0,6-1,0 cm; pecíolo curto a longo, 0,3-3,0 cm $\times 0,5-1,0 \mathrm{~mm}$, levemente alado, com escamas 0,6-1,6 × 0,5-1,2 mm, esparsas, castanho-claras, geralmente ovais, base arredondada, ápice acuminado, margens ciliadas, hialinas; lâmina cartácea a subcoriácea, inteira, com escamas na costa ou próximo da costa abaxialmente, semelhantes às do pecíolo, lâmina estéril elíptica a lanceolada, base atenuada, ápice agudo a arredondado, lâmina fértil linear-lanceolada, base atenuada, ápice agudo, às vezes levemente arredondado; nervuras areoladas, com 1 ou 2 vênulas livres inclusas nas aréolas, visíveis. Soros arredondados a oblongos, localizados medianamente entre a costa e a margem da lâmina, em 2 ou 3 vênulas inclusas nas aréolas; paráfises filiformes, do mesmo comprimento dos esporângios. Material examinado: 27-V-1943, O. Handro s.n. (SP48418); 14-VII-1960, G. Eiten et al. 2103 (SP); 22-VIII-1968, T. Sendulsky 943 (SP); 17-XI-1980, A. Tosta-Silva 260 (SP); 25-XI-1980, N.A. Rosa \& J.M. 
Pires 3848 (SP); 10-VI-2003, J. Prado \& G.B. Silva 1415 (SP).

Distribuição geográfica: Peru, Paraguai, Uruguai, Argentina e Brasil - Mato Grosso, Bahia, Minas Gerais, Rio de Janeiro, São Paulo, Paraná, Santa Catarina e Rio Grande do Sul.

$\mathrm{Na}$ área do PEFI esta é a única espécie do gênero que apresenta escamas do caule com margens ciliadas e ápice agudo. A espécie mais semelhante é Microgramma vacciniifolia, mas difere pelos soros localizados em uma única vênula inclusa nas aréolas, dispostos medianamente entre a costa e a margem da lâmina.

Microgramma vacciniifolia (Langsd. \& Fisch.) Copel., Gen. fil.: 185. $1947 \equiv$ Polypodium vacciniifolium Langsd. \& Fisch., P1. Voy. Russes Monde 8: tab. 7. 1810.

Plantas epífitas. Caule 1,0-2,0 mm diâm., revestido por escamas $3,5-5,0 \times 0,5-0,7 \mathrm{~mm}$, castanhoclaras, lanceoladas, base alargada, levemente truncada, estreitando-se em um ápice filiforme, margens inteiras a denticuladas, às vezes com alguns cílios esparsos. Frondes conspicuamente dimorfas, fronde estéril 2,2-3,8 $\times 0,3-0,6 \mathrm{~cm}$, fronde fértil 0,9$4,1 \times 0,7-1,6 \mathrm{~cm}$; pecíolo quase ausente, 0,1-0,4 $\times$ $0,05 \mathrm{~mm}$; lâmina estéril e fértil subcoriáceas, lâmina fértil linear, com escamas aracnóides, próximas à costa, abaxialmente e nas margens, mais escassas adaxialmente, base cuneada, ápice levemente obtuso a arredondado, margens revolutas; lâmina estéril oval a elíptica, com escamas semelhantes às da lâmina fértil, base cuneada ou truncada, ápice arredondado a levemente obtuso; nervuras imersas no tecido laminar, anastomosadas, parcialmente visíveis; lâmina estéril com até três fileiras de aréolas entre a costa e a margem, terminando livres na margem da lâmina, com aréolas maiores próximas à costa, com uma única vênula inclusa, às vezes bifurcadas, excurrente; lâmina fértil com apenas uma aréola próxima à costa, com uma vênula livre inclusa. Soros arredondados, localizados medianamente entre a costa e a margem da lâmina; paráfises filiformes, mais curtas ou do mesmo comprimento dos esporângios.

Material examinado: 30-VI-1938, O. Handro s.n. (SP44454); 6-X-2003, J. Prado \& D.M. Vital 1433 (SP); 20-XII-2005, J. Prado \& G.B. Silva 1624 (SP).

Distribuiçao geográfica: Antilhas, Venezuela, Colômbia, Paraguai, Argentina e Brasil Pernambuco, Bahia, Mato Grosso, Mato Grosso do Sul, Minas Gerais, Espírito Santo, Rio de Janeiro, São Paulo, Paraná, Santa Catarina e Rio Grande do Sul.
Microgramma vacciniifolia é facilmente reconhecida no PEFI por apresentar escamas do caule com ápice filiforme e pela presença de escamas aracnóides na lâmina.

\section{Pecluma M.G. Price}

Plantas terrestres, rupícolas ou epífitas. Caule horizontal, curto a longo-reptante, delgado ou robusto, não ramificado, dorsiventral (frondes formadas na superfície dorsal), com escamas basifixas, não clatradas, linear-lanceoladas a ovais, glabras ou comosas; pecíolos articulados, cilíndricos. Frondes estéreis e férteis monomorfas; lâmina pectinada (pinatissecta com segmentos lineares, estreitos e paralelos entre si), oblongas a lineares; segmentos geralmente lineares, adnados, próximos entre si, inteiros; raque cilíndrica, pubescente adaxialmente, indumento com escamas e/ou tricomas ou raque glabra abaxialmente; nervuras simples ou 1-2-furcadas, visíveis ou ocultas. Soros arredondados, unisseriados, localizados um em cada lado da costa; paráfises presentes em algumas espécies; esporângios longo pedicelados, com ou sem sétulas na cápsula.

Pecluma compreende cerca de 28 espécies, sendo que todas são neotropicais. Este gênero é caracterizado principalmente pela presença de frondes pectinadas, com pecíolo e raque cilíndricos (Mickel \& Smith 2004).

Chave para as espécies de Pecluma

1. Caule delgado, ca. 0,2 cm diâm., escamas ovallanceoladas com ápice agudo; segmentos ascendentes .................................. P. truncorum

1. Caule robusto, 0,5-0,8 cm diâm., escamas deltóidelanceoladas ou oval-lanceoladas com ápice filiforme, segmentos perpendiculares a raque

2. Frondes ca. $1,50 \mathrm{~m} \times 22,0 \mathrm{~cm}$; lâmina cartácea; esporângios com sétulas na cápsula ...P. paradiseae

2. Frondes $21,0-24,5 \times 3,1-4,3 \mathrm{~cm}$; lâmina subcoriácea; esporângio sem sétula na cápsula P. singeri

Pecluma paradiseae (Langsd. \& Fisch.) M.G. Price, Amer. Fern J. 73: 115. $1983 \equiv$ Polypodium paradiseae Langsd. \& Fisch., P1. Voy. Russes Monde 11: tab. 11. 1810.

Figura 1 A-E

Plantas terrestres. Caule longo-reptante, robusto, $0,8 \mathrm{~cm}$ diâm., revestido por escamas, 2,9-3,7 × 0,2$1,0 \mathrm{~mm}$, castanho-escuras, deltóide-lanceoladas, base 
levemente truncada a cordada, com ápice filiforme, às vezes quase linear, margens inteiras, às vezes com alguns dentes. Frondes ca. 1,50 m $\times 22,0 \mathrm{~cm}$; pecíolo $21,5 \times 0,4-0,5 \mathrm{~cm}$, castanho-escuro, com tricomas simples, hialinos, levemente castanho-avermelhados, às vezes alvos, 0,3-0,6 mm compr.; lâmina cartácea, pinada na base, pinatissecta quase encostando à costa na região mediana até o ápice, oblongo-lanceolada, gradualmente atenuada e terminando em segmentos auriculiformes na base, ápice com os segmentos mais próximos entre si e terminando abruptamente, com tricomas simples, semelhantes aos do pecíolo, abaxialmente na raque, costa, nervuras, tecido laminar e margens, adaxialmente mais escassos sobre as nervuras e tecido laminar; segmentos perpendiculares à raque, lineares, os maiores com $11,6 \times 0,7 \mathrm{~cm}$, margens inteiras ou levemente crenadas, mais distantes entre si quanto mais próximos da base da lâmina; nervuras livres, 1 ou 2-furcadas, visíveis, terminando próximo à margem da lâmina. Soros arredondados, localizados no ápice das nervuras, medianamente entre a costa e a margem da lâmina; paráfises simples, aciculares; esporângios com sétulas na cápsula.

Material examinado: 27-VIII-1951, O. Handro 258 (SP). Distribuição geográfica: Endêmica do Brasil - Minas Gerais, Espírito Santo, Rio de Janeiro, São Paulo, Paraná, Santa Catarina e Rio Grande do Sul.

Pecluma paradiseae é uma espécie facilmente reconhecida por ser uma planta bastante robusta (com ca. de $1,50 \mathrm{~m} \times 22 \mathrm{~cm})$ vs. $P$. singeri e $P$. truncorum $(21,0-24,5 \times 3,1-4,3 \mathrm{~cm}, 16,0-38,0 \times 1,7-3,4 \mathrm{~cm}$, respectivamente). Além disso, dentre as espécies do PEFI é a única espécie que apresenta esporângios com sétulas na cápsula.

Pecluma singeri (de la Sota) M.G. Price, Amer. Fern J. 73: $115.1983 \equiv$ Polypodium singeri de la Sota, Opera Lilloana 5: 181. 1960.

Figura 1 F-I

Plantas epífitas. Caule horizontal, curto-reptante, levemente robusto, $0,5 \mathrm{~mm}$ diâm., revestido por escamas, 3,0-3,5 × 0,2-0,5 mm, castanho-escuras, oval-lanceoladas, levemente truncadas, com ápice filiforme, às vezes quase lineares, margens inteiras, às vezes com alguns dentes esparsos. Frondes 21,0$24,5 \times 3,1-4,3 \mathrm{~cm}$; pecíolo $2,0-2,5 \times$ ca. $0,1 \mathrm{~cm}$, castanho-escuro, com tricomas simples, 0,3-0,6 mm compr., tricomas ramificados, 0,1-0,2 mm compr., ambos hialinos, levemente castanho-avermelhados; lâmina subcoriácea, pinada na base, pinatissecta quase encostando à costa na região mediana até o ápice, oblongo-lanceolada, abruptamente atenuada e terminando em segmentos auriculiformes na base, gradualmente reduzindo para o ápice, às vezes, terminando em um segmento alongado, adaxialmente com textura papilosa e brilhante, com tricomas simples e ramificados abaxialmente na raque, costa, nervuras e margens, raramente no tecido laminar, semelhantes aos do pecíolo, adaxialmente mais escassos sobre as nervuras, com escamas unisseriadas, filiformes, adpressas, castanhoavermelhadas, 0,1-0,2 $\mathrm{mm}$ compr., abaxialmente principalmente sobre nervuras e tecido laminar, mais escassas adaxialmente; segmentos perpendiculares à raque, lineares, os maiores com $2,3 \times 0,2 \mathrm{~cm}$, margens inteiras, uniformemente distantes entre si; nervuras geralmente 1-furcada, às vezes simples no ápice dos segmentos, inconspícuas, terminando próximas à margem da lâmina. Soros arredondados, localizados submarginalmente; paráfises simples, clavadas; esporângios sem sétulas na cápsula.

Material examinado:25-VII-1951,O.Handro 256(SP). Distribuição geográfica: Paraguai, Argentina e Brasil - Minas Gerais, São Paulo, Paraná, Santa Catarina e Rio Grande do Sul.

Segundo de la Sota (1960), esta espécie difere das outras basicamente pela forma de crescimento de seu caule, curto-reptante, ereto, com duas fileiras de cicatrizes foliares evidentes e frondes aglomeradas no extremo superior.

Pecluma singeri apresenta tricomas ramificados principalmente na raque e costa abaxialmente, com 0,1-0,2 mm compr., que são muito semelhantes aqueles encontrados em Micropolypodium achilleifolium.

Pecluma truncorum (Lindm.) M.G. Price, Amer. Fern J. 73: 115. $1983 \equiv$ Polypodium truncorum Lindm., Hedwigia 43: 309. 1904.

Figura $1 \mathrm{~J}-\mathrm{M}$

Plantas epífitas. Caule horizontal, curto-reptante, delgado, 0,2 cm diâm., revestido por escamas, 0,9-1,3 $\times$ 0,5-0,6 mm, castanho-escuras, ovallanceoladas, base levemente cordada, ápice agudo, margens inteiras. Frondes 16,0-38,0 × 1,7-3,4 cm; pecíolo cilíndrico, alado, 1,0-4,5 $\mathrm{cm} \times 0,5-1,0 \mathrm{~mm}$, castanho-claras a castanho-escuras, com tricomas simples, 0,5-0,9 mm compr., hialinos, levemente castanho-avermelhados, às vezes alvos; lâmina membranácea, pinatissecta quase encostando na costa, lanceolada, gradualmente atenuada na base 


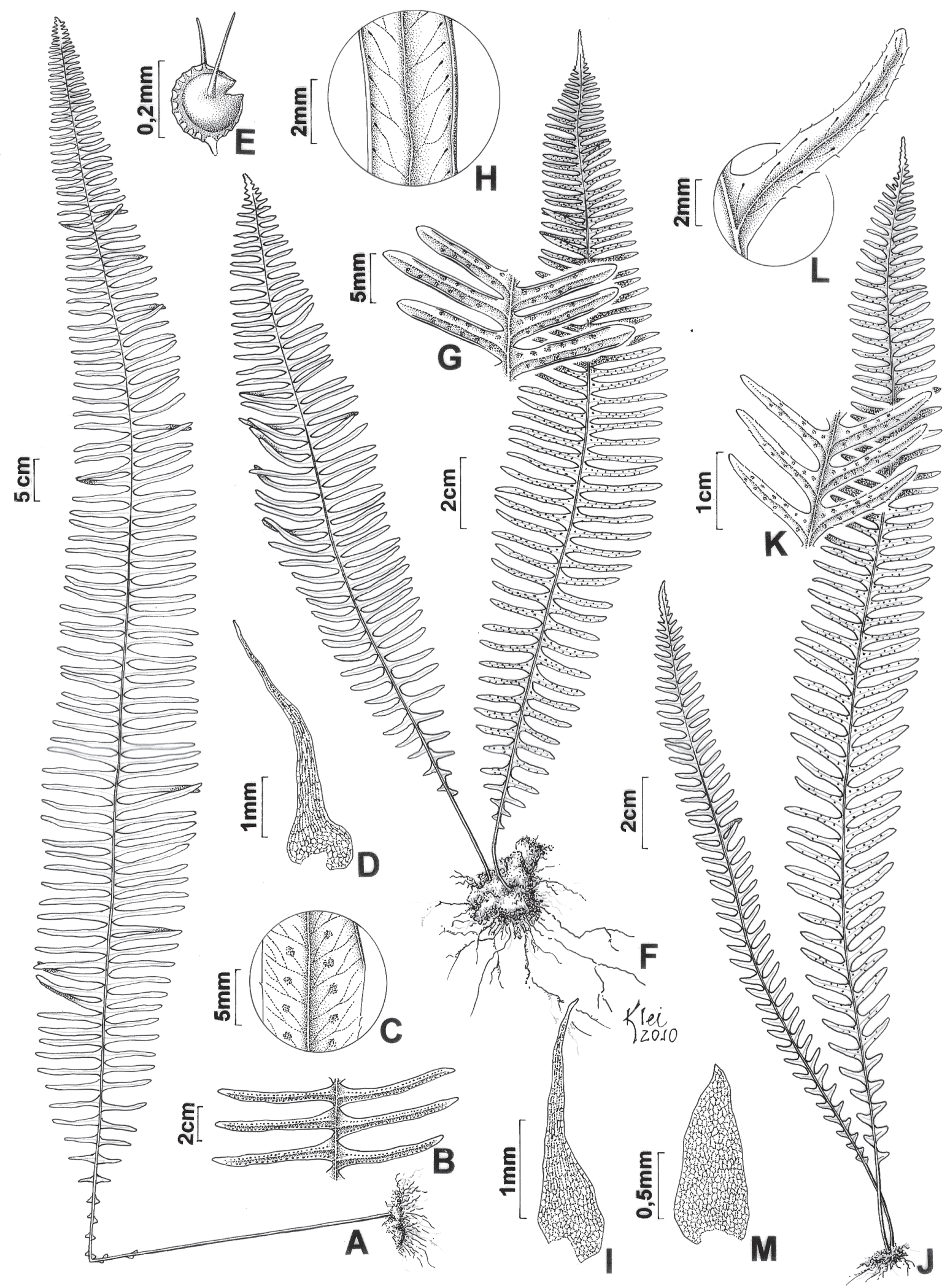

Figura 1. A-E. Pecluma paradiseae (Handro 258). A. Hábito. B. Detalhe dos segmentos abaxialmente. C. Detalhe das nervuras no segmento abaxialmente. D. Escama do caule. E. Esporângio com sétulas. F-I. Pecluma singeri (Handro 256). F. Hábito. G. Detalhe dos segmentos abaxialmente. H. Detalhe das nervuras no segmento abaxialmente (diafanizado). I. Escama do caule. J-M. Pecluma truncorum (Hoehne s.n., SP28458). J. Hábito. K. Detalhe dos segmentos abaxialmente. L. Detalhe das nervuras no segmento abaxialmente. M. Escama do caule.

Figure 1. A-E. Pecluma paradiseae (Handro 258). A. Habit. B. Detail of the segments abaxially. C. Detail of the veins on the segment abaxially. D. Stem scale. E. Sporangium with setules. F-I. Pecluma singeri (Handro 256). F. Habit. G. Detail of the segments abaxially. H. Detail of the veins on the segment abaxially (clarified). I. Stem scale. J-M. Pecluma truncorum (Hoehne s.n., SP28458). J. Habit. K. Detail of the segments abaxially. L. Detail of the veins on the segment abaxially. M. Stem scale. 
e terminando abruptamente no ápice, com tricomas simples abaxialmente na raque, costa, nervuras e margens, semelhantes aos do pecíolo, adaxialmente mais escassos, com escamas unisseriadas, filiformes, adpressas, castanho-avermelhadas, adpressas, 0,1-0,2 mm compr., principalmente sobre nervuras e tecido laminar abaxialmente, mais escassas adaxialmente; segmentos ascendentes, lineares, subulados em direção ao ápice, os maiores com 2,6 cm $\times 2,5 \mathrm{~mm}$, margens inteiras ou levemente crenadas, uniformemente distantes entre si; nervuras livres, simples, às vezes furcadas na base dos segmentos, visíveis, terminando próximas das margens da lâmina. Soros arredondados, localizados no ápice das nervuras, submarginalmente; paráfises simples, aciculares, inconspícuas; esporângios sem sétulas na cápsula. Material examinado: 13-VI-1931, F.C. Hoehne s.n. (SP28458); 10-X-1970, O. Handro 2149 (SP, SPF).

Distribuição geográfica: Argentina e Brasil - Bahia, Minas Gerais, Espírito Santo, Rio de Janeiro, São Paulo, Paraná, Santa Catarina e Rio Grande do Sul.

Esta espécie é caracterizada pelo caule curtoreptante; frondes com lâmina membranácea; segmentos subulados, em direção ao ápice da fronde e nervuras laterais simples, raramente furcadas na base dos segmentos (de la Sota 1960).

$\mathrm{Na}$ área do PEFI, esta espécie foi encontrada como epífita sobre a samambaia arborescente Alsophila setosa Kaulf.

Phlebodium (R. Br.) J. Sm.

Plantas epífitas ou rupícolas. Caule longo-reptante, ramificado, com escamas peltadas, não clatradas, com margens ciliadas; frondes patentes a eretas, monomorfas, articuladas aos filopódios; pecíolo sulcado na face adaxial; lâmina cartácea a coriácea, pinatissecta, base truncada, ápice semelhante a um segmento lateral, glabra ou raramente com escamas, frequentemente com tonalidade glauca; segmentos inteiros; nervuras irregularmente anastomosadas, as aréolas com uma, duas ou nenhuma vênula livre inclusa, visíveis. Soros abaxiais, arredondados, localizados no ápice da vênula inclusa ou nas aréolas, não protegidos por escamas; paráfises ausentes.

Phlebodium pode ser facilmente reconhecido pela frequente tonalidade glauca da lâmina (in vivo), e pelas nervuras irregularmente anastomosadas. Segundo de la Sota (1960), Moran (1995b) e Mickel \& Smith (2004), este é um gênero neotropical, com cerca de quatro ou cinco espécies amplamente distribuídas.

Algumas espécies são amplamente cultivadas, inclusive no continente Europeu, com finalidade ornamental.

Phlebodium areolatum (Humb. \& Bonpl. ex Willd.) J. Sm., J. Bot. (Hooker) 4: 59. 1841 三 Polypodium areolatum Humb. \& Bonpl. ex Willd., Sp. pl. 5: 172. 1810.

Plantas epífitas ou rupícolas. Caule, 1,0-1,5 cm diâm., com escamas 6,5-12,0 × 1,5-2,8 mm, castanhoclaras a alaranjadas, oval-lanceoladas a linearlanceoladas, base cordada ou levemente truncada a arredondada, ápice filiforme, margens denticuladas a ciliadas; frondes patentes, $60,0-90,0 \times 20,0-25,0$ $\mathrm{cm}$; pecíolo sulcado na face adaxial, $25,0-40,0 \mathrm{~cm}$ $\times$ 2,0-4,0 mm, castanho, lustroso; lâmina cartácea, pinatissecta, com 10-15 pares de segmentos, oval, com a base truncada, glabra; segmentos patentes a ascendentes, os medianos com 12,0-15,0 × 2,0-2,5 $\mathrm{cm}$, com o ápice agudo, alas entre os segmentos com 0,5-1,0 cm larg.; nervuras não atingindo a margem dos segmentos, proeminentes na face abaxial; hidatódios presentes com secreções calcárias. Soros arredondados, localizados sobre o ápice das vênulas livres inclusas, dispostos em uma fileira entre a cóstula (em ambos os lados, próximos a ela) e a margem do segmento, geralmente mais de 25 pares por segmento, presentes em todos os segmentos, no ápice da lâmina e ocasionalmente nas alas entre os segmentos.

Material examinado: 17-IX-2008, R.Y. Hirai \& P.B. Schwartsburd 592 (SP).

Distribuição geográfica: Amplamente distribuída no Neotrópico no sudeste dos EUA, México, Guatemala, Honduras, El Salvador, Nicaraguá, Costa Rica, Panamá, Grandes e Pequenas Antilhas, Colômbia, Venezuela, Trinidad, Guiana, Suriname, Guiana Francesa, Equador, Peru, Bolívia, Argentina, Paraguai e Brasil - Mato Grosso do Sul, Minas Gerais, Rio de Janeiro, São Paulo, Paraná, Santa Catarina e Rio Grande do Sul.

Phlebodium aureum (L.) J. Sm. e P. decumanum (Willd.) J. Sm. são as espécies mais semelhantes, mas diferem de $P$. areolatum pelo maior número de séries de soros localizados entre a cóstula e a margem da lâmina ( 2 a 3 e 3 a 7, respectivamente) e não ocorrem na área do PEFI.

No PEFI, esta espécie ocorre preferencialmente como epífita de palmeiras, principalmente nas áreas alteradas.

Pleopeltis Humb. \& Bonpl. ex Willd. 
Plantas epífitas ou rupícolas. Caule reptante, ramificado ou não, com escamas peltadas, subclatradas a clatradas, com margens inteiras, denteadas ou comosas (com tricomas no ponto de inserção); frondes patentes a eretas, monomorfas ou dimorfas, articuladas aos filopódios; lâmina cartácea a coriácea, inteira, pinatissecta ou 1-pinada, com a base truncada ou gradualmente reduzida, com o ápice semelhante a um segmento lateral ou pinatífido, com escamas; pinas ou segmentos (quando presentes) inteiros, lineares ou auriculados; nervuras irregularmente anastomosadas, as aréolas com uma a várias vênulas livres inclusas, ocultas. Soros arredondados, oblongos ou lineares, localizados na junção da maioria das vênulas inclusas, com uma fileira de soros de cada lado da costa, proeminentes, recobertos por escamas; esporângios glabros; esporos monoletes.

Pleopeltis também é um gênero que foi segregado de Polypodium s.l. e compreende cerca de 15-20 espécies (excluindo Lepisorus da Ásia) (Mickel \& Smith 2004). Entretanto, estudos mais recentes baseados em filogenia molecular (Schneider et al. 2004) redefiniram o gênero, que conta agora com ca. 75 espécies (Kessler \& Smith 2005), sendo a maioria neotropical com poucas ocorrendo na África. Pode ser facilmente reconhecido por apresentar escamas peltadas e arredondadas na lâmina e nos soros imaturos, a lâmina varia de inteira a pinatissecta, aréolas com vênulas livres inclusas e soros localizados na junção da maioria das vênulas inclusas (Mickel \& Smith 2004).

\section{Chave para as espécies de Pleopeltis}

1. Lâmina inteira; escamas do caule comosas; soros oblongos ................................. P. astrolepis

1. Lâmina pinatissecta, subdicotomicamente dividida ou 1-pinada; escamas do caule não comosas; soros arredondados

2. Lâmina pinatissecta, subdicotomicamente dividida, aeróforo ausente ..... P. pleopeltifolia

2. Lâmina 1-pinada, com uma aurícula acroscópica na base, com um aeróforo na aurícula acroscópica de cada pina ........ P. hirsutissima

Pleopeltis astrolepis (Liebm.) E. Fourn., Mexic. P1. 1: $87.1872 \equiv$ Polypodium astrolepis Liebm., Mexic. Bregn.: 185. 1849.

Plantas epífitas. Caule longo-reptante, 0,4-1,2 mm diâm., com escamas clatradas, comosas, 0,3-0,4 $\times$ 0,2-0,3 mm, negras, ovais ou levemente deltóides, base arredondada, ápice arredondado ou levemente agudo, margens denticulado-laceradas, tricomas na superfície da escama com ca. 0,1-0,6 mm compr.; frondes monomorfas, patentes, 7,0-11,0 cm $\times 4,0$ $6,0 \mathrm{~mm}$; pecíolo cilíndrico, quase ausente, ca. $1,0 \times$ $0,05 \mathrm{~mm}$, castanho; lâmina coriácea, inteira, linearlanceolada, com a base longamente decurrente, ápice agudo a levemente arredondado, com escamas clatradas, ovais a lanceoladas, margens ciliadas, sobre o tecido laminar e costa (em ambas as superfícies da lâmina), aeróforos ausentes; nervuras ocultas. Soros oblongos, localizados em depressões da lâmina, de três a oito pares.

Material examinado: 14-VII-1960, G. Eiten et al. 2107 (SP).

Distribuição geográfica: Amplamente distribuída no Neotrópico no Sudeste dos EUA, México, Guatemala, Belize, Honduras, El Salvador, Nicaraguá, Costa Rica, Panamá, Grandes e Pequenas Antilhas, Colômbia, Venezuela, Trinidad, Suriname, Guiana Francesa, Peru, Bolívia e Brasil - Pernambuco, Alagoas, Bahia, Mato Grosso do Sul, Rio de Janeiro, Espírito Santo, Minas Gerais, São Paulo, Paraná, Santa Catarina e Rio Grande do Sul.

Segundo Mickel \& Smith (2004), dentre as espécies de Pleopeltis que apresentam lâmina inteira (por exemplo, P. macrocarpa (Bory ex Willd.) Kaulf.), P. astrolepis é facilmente reconhecida pelos soros oblongos e pecíolo muito curto, pequeno, com escamas comosas.

Pleopeltis hirsutissima (Raddi) de la Sota in Zuloaga et al., Darwiniana 45: 239. $2007 \equiv$ Polypodium hirsutissimum Raddi, Opusc. Sci. Bol. 3: 286. 1819.

Plantas epífitas. Caule longo-reptante, 3,0-6,0 mm diâm., com escamas subclatradas, 2,0-3,0 × 0,6$1,0 \mathrm{~mm}$, castanho-claras, lanceoladas a oval-lanceoladas, base arredondada, ápice acuminado, margens ciliadas; frondes monomorfas, patentes ou eretas, 21,0-43,0 × 2,5-4,5 cm; pecíolo cilíndrico, castanho-escuro, 1,0-3,0 cm × 1,0-2,0 mm; lâmina coriácea, 1-pinada, linear-lanceolada, com ca. 50 pares de pinas,cada uma com uma aurícula na base, com escamas subclatradas, lanceoladas a oval-lanceoladas, margens ciliadas, sobre a raque e costa (em ambas as superfícies da lâmina), escamas gonfóides sobre o tecido laminar e nervuras (em ambas as superfícies da lâmina, abaxialmente recobrindo quase que totalmente o tecido laminar), com um aeróforo na aurícula acroscópica de cada pina; nervuras ocultas. Soros 
arredondados, circundados de escamas da lâmina. Material examinado: s.d., J.A. Corrêa 132 (SP); 20VII-1939, O. Handro s.n. (SP44455); 14-VII-1960, G. Eiten et al. 2105 (SP); 23-IV-1979, A.Tosta-Silva 308 (SP); 20-XII-2005, J. Prado \& G.B. Silva 1625 (SP). Distribuição geográfica: Bolívia, Argentina, Uruguai, Paraguai e Brasil - Goiás, Distrito Federal, Mato Grosso, Mato Grosso do Sul, Minas Gerais, Espírito Santo, Rio de Janeiro, São Paulo, Paraná, Santa Catarina e Rio Grande do Sul.

Pleopeltis hirsutissima é uma espécie bastante comum, bem característica por apresentar escamas gonfóides (base arredondada e um longo ápice) sobre o tecido laminar em ambas as superfícies da lâmina, sendo que a face abaxial é quase que completamente recoberta por essas escamas.

Pleopeltis pleopeltifolia (Raddi) Alston, Bol. Soc. Broteriana 30: 21. 1956 三 Polypodium pleopeltifolium Raddi, Opusc. Sci. Bol. 3: 286. 1819.

Plantas epífitas. Caule curto-reptante, 2,0-5,0 mm diâm., com escamas subclatradas, 1,8-3,2 × 0,2-0,5 $\mathrm{mm}$, negras, lanceoladas, margens laceradas, hialinas; frondes monomorfas, patentes ou eretas, 12,0-14,5 $\times$ 7,5-8,7 cm; pecíolo canaliculado na face adaxial, com duas aletas clorofiladas decurrentes à lâmina, 2,5-5,3 $\mathrm{cm} \times 1,0-1,5 \mathrm{~mm}$, castanho-escuro; lâmina cartácea, pinatissecta, subdicotomicamente dividida, com ca. 5 segmentos, com escamas subclatradas, lanceoladas a oval-lanceoladas, margens laceradas a levemente laceradas, hialinas, esparsas sobre a costa, cóstula, nervuras e tecido laminar (em ambas as superfícies da lâmina), aeróforos ausentes; nervuras ocultas. Soros arredondados.

Material examinado: 17-IX-2008, R.Y. Hirai \& P.B. Schwartsburd 591 (SP).

Distribuição geográfica: Argentina, Uruguai, Paraguai e Brasil - Ceará, Pernambuco, Bahia, Goiás, Mato Grosso, Mato Grosso do Sul, Minas Gerais, Espírito Santo, Rio de Janeiro, São Paulo, Paraná, Santa Catarina e Rio Grande do Sul.

Pleopeltis pleopeltifolia é facilmente reconhecida pela lâmina pinatissecta, subdicotomicamente dividida. A espécie mais semelhante é $P$. angusta Humb. \& Bonpl. ex Willd., porém esta última diferencia-se por possuir as escamas do caule comosas e ocorre apenas no México e Mesoamérica) (Lorea-Hernández 1995, Nóbrega \& Prado 2008).

Esta espécie é muito comum no PEFI, ocorrendo como epífita, tanto no interior da Floresta, como em áreas alteradas.

\section{Serpocaulon A.R. Sm.}

Plantas epífitas ou rupícolas, raramente terrestres. Caule longo-reptante, ramificado, com escamas peltadas, clatradas, com margens inteiras ou denteadas; frondes patentes a eretas, monomorfas, articuladas aos filopódios; pecíolo sulcado adaxialmente; lâmina papirácea a coriácea, pinatissecta ou 1-pinada, com a base truncada, com o ápice semelhante a um segmento lateral ou pinatífido, glabra ou com tricomas unisseriados, tricomas glandulares ou com escamas; pinas ou segmentos (quando presentes) inteiros, lineares, lanceolados ou falcados; nervuras anastomosadas do tipo gonioflebóide, as aréolas com apenas uma vênula livre inclusa, visíveis ou ocultas. Soros arredondados, localizados no ápice da vênula livre inclusa; paráfises presentes ou ausentes.

Serpocaulon foi recentemente segregado do gênero Polypodium s.l. por Smith et al. (2006a), uma vez que é um grupo monofilético. Apresenta ca. de 40 espécies neotropicais, ocorrendo nas matas úmidas nas regiões dos Andes e do sudeste e sul do Brasil. A sua característica principal é a presença de nervuras areoladas do tipo gonioflebóide, caule longo-reptante, com escamas geralmente peltadas e clatradas (Smith et al. 2006a). Labiak \& Prado (2008) publicaram um conspecto das espécies da Floresta Atlântica brasileira nas regiões sul e sudeste.

\section{Chave para espécies de Serpocaulon}

1. Lâmina 1-pinada, com secreções esbranquiçadas nas terminações das nervuras da lâmina adaxialmente .............................. S. meniscifolium

1. Lâmina pinatissecta, sem secreções esbranquiçadas nas terminações das nervuras da lâmina adaxialmente

2. Caule pruinoso; lâmina glabra ou com escamas filiformes inconspícuas sobre a costa e cóstula abaxialmente S. catharinae

2. Caule não pruinoso; lâmina com tricomas claviformes inconspícuos ou com tricomas claviformes esparsos e escamas filiformes inconspícuas sobre a costa e cóstula abaxialmente

3. Lâmina subcoriácea; nervuras proeminentes, visíveis S. vacillans

3. Lâmina papirácea; nervuras não proeminentes, ocultas S. sehnemii

Serpocaulon catharinae (Langd. \& Fisch.) A.R. Sm., 
Taxon 55: 928. $2006 \equiv$ Polypodium catharinae Langsd. \& Fisch., P1. Voy. Russes Monde 1: tab. 9. 1810 .

Plantas epífitas. Caule 3,0-6,0 mm diâm., pruinoso, com escamas peltadas, 1,2 -4,0 × 0,5-1,2 $\mathrm{mm}$, castanho-escuras, ovais a oval-lanceoladas, base arredondada, ápice acuminado, margens inteiras a levemente laceradas; frondes patentes ou eretas, $14,0-49,0 \times 9,0-16,0 \mathrm{~cm}$; pecíolo sulcado adaxialmente, amarelado, 8,0-23,0 $\mathrm{cm} \times 1,4-2,0$ $\mathrm{mm}$; lâmina cartácea, pinatissecta, oval ou rômbica, com ca. 11-25(-30) pares de segmentos, glabra ou com escamas filiformes inconspícuas sobre a costa e cóstula abaxialmente; nervuras anastomosadas, não atingindo a margem dos segmentos, ocultas. Soros arredondados, dispostos em uma fileira entre a costa e a margem da lâmina.

Material examinado: 8-VII-1939, O. Handro s.n. (SP44457); 11-II-1956, W. Hoehne s.n. (SP119668); 14-VII-1960, G. Eiten et al. 2102 (SPF); 14-VII1960, G. Eiten et al. 2108-C (SP); 21-XI-1980, N.A. Rosa \& J.M. Pires 3831 (SP); 20-XII-2005, J. Prado \& G.B. Silva 1606 (SP).

Distribuição geográfica: Argentina, Uruguai, Paraguai e Brasil - Bahia, Minas Gerais, Espírito Santo, Rio de Janeiro, São Paulo, Paraná, Santa Catarina e Rio Grande do Sul.

Esta espécie é facilmente reconhecida pela tonalidade verde azulada do caule nas plantas in vivo, ou pela tonalidade preta e pruinosa (com depósitos de cristais) nos materiais herborizados. Diferencia-se, também, das demais espécies congenéricas presentes no PEFI, pelas características utilizadas na chave.

Serpocaulon catharinae é muito comum no PEFI, ocorrendo exclusivamente como epífita, no interior da floresta e também em áreas alteradas.

Serpocaulon meniscifolium (Langsd. \& Fisch.) A.R. Sm, Taxon 55: 928. $2006 \equiv$ Polypodium meniscifolium Langsd. \& Fisch., Pl. Voy. Russes Monde 11: tab. 11. 1810.

Plantas epífitas. Caule 6,0-10,0 mm diâm., não pruinoso, com escamas peltadas, 2,4-3,8 $\times 2,0-2,5 \mathrm{~mm}$, castanho-claras, ovais, oblongas ou oval-lanceoladas, base arredondada, ápice agudo, margens irregulares, amareladas; frondes patentes ou eretas, 52,0-85,0 $\times$ 20,0-30,0 cm; pecíolo sulcado adaxialmente, 22,0-30,0 cm × 1,5-4,0 mm, castanho-claro; lâmina cartácea, 1-pinada, rômbica, com ca. 12-25 pares de pinas, com escamas peltadas, ovais a lanceoladas, na raque e costa abaxialmente, com tricomas aciculares inconspícuos sobre a raque, costa, nervuras e tecido laminar abaxialmente, esparsos adaxialmente; pinas medianas com o lado acroscópico adnado à raque e o basiscópico livre; nervuras anastomosadas, atingindo a margem dos segmentos, proeminentes no tecido laminar, visíveis, terminações das nervuras adaxialmente com secreções esbranquiçadas. Soros arredondados, dispostos em duas ou três fileiras entre a costa e a margem da lâmina.

Material examinado: XII-1950, O. Handro 213 (SP); 20-X-2003, J. Prado \& D.M. Vital 1449 (SP).

Distribuição geográfica: Endêmica da Floresta Atlântica brasileira; Brasil - Bahia, Minas Gerais, Espírito Santo, Rio de Janeiro, São Paulo, Paraná, Santa Catarina e Rio Grande do Sul.

Serpocaulon meniscifolium é facilmente reconhecida pela presença de tricomas na lâmina abaxialmente e com escamas ovais a lanceoladas na raque e costa. A presença de secreções esbranquiçadas nas terminações das nervuras adaxialmente é bastante peculiar nessa espécie e a difere das outras que ocorrem no PEFI.

Esta é a única espécie de Serpocaulon com a lâmina pinada ocorrente no PEFI. Ocorre preferencialmente como epífita, principalmente sobre palmeiras, tanto no interior da Floresta como em áreas alteradas.

Serpocaulon sehnemii (Pic. Serm.) Labiak \& J. Prado, Amer. Fern J. 98: 153. $2008 \equiv$ Goniophlebium sehnemii Pic. Serm., Webbia 60: 108, fig. 19. 2005, nom. nov. para Polypodium laetum Raddi, Syn. Fil. Bras.: 9. 1819, non Salisbury (1796).

Plantas terrestres. Caule 2,0-4,0 mm diâm., não pruinoso, com escamas peltadas, 1,5-4,0 × 0,4-0,8 $\mathrm{mm}$, castanho-escuras, ovais a oval-lanceoladas, base arredondada, ápice acuminado, margens inteiras; frondes eretas, 28,0-45,0 × 10,0-15,0 cm; pecíolo sulcado adaxialmente, $10,0-20,0 \mathrm{~cm} \times 1,0-1,7 \mathrm{~mm}$, amarelado; lâmina papirácea, pinatissecta, lanceolada, com ca. 10-15 pares de segmentos, glabrescente, com tricomas claviformes inconspícuos sobre a costa e cóstula abaxialmente; nervuras anastomosadas, não atingindo a margem dos segmentos, ocultas. Soros arredondados, dispostos em duas ou raramente três fileiras entre a costa e a margem da lâmina.

Material examinado: 4-I-1975, O. Handro 2268(SPF). Distribuição geográfica: Endêmica da Floresta Atlântica brasileira; Brasil - Minas Gerais, Espírito Santo, Rio de Janeiro, São Paulo, Paraná, Santa Catarina e Rio Grande do Sul. 
Segundo Labiak \& Prado (2008), Serpocaulon sehnemii é caracterizada pela sua lâmina de textura papirácea e pelas nervuras secundárias e terciárias não proeminentes na superfície abaxial da lâmina.

Esta espécie é um tanto quanto rara no PEFI, assim como ao longo de sua distribuição (Labiak \& Prado 2008). Ocorre como terrestre, no interior da Floresta.

Serpocaulon vacillans (Link) A.R. Sm., Taxon 55: 929. 2006 三 Polypodium vacillans Link, Hort. Berol. 2: 97. 1833.

Plantas terrestres. Caule 5,0-10,0 mm diâm., não pruinoso, com escamas peltadas, 2,0-3,5 × 1-1,8 $\mathrm{mm}$, ovais-lanceoladas, base arredondada, ápice acuminado, margens inteiras a levemente crenadas; frondes eretas, 40,0-65,0 × 11,0-18,0 cm; pecíolo sulcado adaxialmente, $20,0-30,0 \mathrm{~cm} \times 2,0-4,0 \mathrm{~mm}$, amarelado; lâmina subcoriácea, pinatissecta, oval ou lanceolada, com ca. 20-30 pares de segmentos, com tricomas claviformes esparsos sobre a costa, cóstula, nervuras, tecido laminar e margens da lâmina abaxialmente, inconspícuos adaxialmente, com escamas filiformes inconspícuas sobre a costa e base das cóstulas abaxialmente; nervuras anastomosadas, não atingindo a margem dos segmentos, proeminentes no tecido laminar, visíveis. Soros arredondados, dispostos em uma ou duas fileiras entre a costa e a margem da lâmina.

Material examinado: 5-VIII-1948, W. Hoehne 2639 (SPF).

Distribuição geográfica: Bolívia, Argentina, Paraguai e Brasil - Mato Grosso, Mato Grosso do Sul, Minas Gerais, Espírito Santo, Rio de Janeiro, São Paulo, Paraná, Santa Catarina e Rio Grande do Sul.

Serpocaulon vacillans assemelha-se, de modo geral, a $S$. sehnemii, porém difere por esta apresentar lâmina papirácea, nervuras secundárias e terciárias não proeminentes na superfície abaxial da lâmina (Labiak \& Prado 2008). Além disso, há somente tricomas na lâmina abaxialmente, ou seja, sem escamas filiformes sobre a costa e base das cóstulas.

$\mathrm{Na}$ área do PEFI, esta espécie ocorre no interior da Floresta e em áreas abertas.

\section{Agradecimentos}

Ao CNPq pela concessão da Bolsa de Produtividade em Pesquisa e auxílio para este projeto (processo 300843-93-3).

\section{Literatura citada}

Arantes, A.A., Prado, J. \& Ranal, M. A. 2010. Polypodiaceae e Pteridaceae da Estação Ecológica do Panga, Uberlândia, Estado de Minas Gerais, Brasil. Revista Brasileira de Botânica 33: 167-183.

Assis, E.L.M \& Labiak, P.H. 2009. Polypodiaceae da borda oeste do Pantanal sul-matogrossense, Brasil. Revista Brasileira de Botânica 32: 233-247.

Baker, J.G. 1870. Cyatheaceae et Polypodiaceae. In: C.F.P. Martius \& A.G. Eichler (eds.). Flora Brasiliensis. Fleischer, Leipzig, v.1, pars 2, pp. 307-334.

Boldrin, A.H.L. \& Prado, J. 2007. Pteridófitas terrestres e rupícolas do Forte dos Andradas, Guarujá, São Paulo, Brasil. Boletim de Botânica da Universidade de São Paulo 25: 1-69.

Copeland, E.B. 1947. Genera filicum. Chronica Botanica, Waltham.

de la Sota,E.R. 1960. Polypodiaceae y Grammitidaceae argentinas. Opera Lilloana 5: 1-229.

Fidalgo, O. \& Bononi, V.L.R. (coords.). 1984. Técnicas de coleta, preservação e herborização de material botânico. Manual 4. Instituto de Botânica, São Paulo.

Hoehne, F.C., Kuhlmann, M. \& Handro, O. 1941. O Jardim Botânico de São Paulo. Departamento de Botânica do Estado, Secretaria da Agricultura, Indústria e Comércio, São Paulo.

Kessler, M. \& Smith, A.R. 2005. Seven new species, 13 new combinations, and one new name of Polypodiaceae (Pteridophyta) from Bolivia. Candollea 60: 271-288.

Labiak, P.H. \& Condack, J.P. 2008. Ceradenia itatiaiensis, a new species of Polypodiaceae from southeastern Brazil. Novon 18: 495-497.

Labiak, P.H. \& Matos, F.B. 2007. A new hybrid and two new combinations in neotropical grammitid ferns. Brittonia 59: 182-185.

Labiak, P.H. \& Prado, J. 1998. Pteridófitas epífitas da Reserva Volta Velha, Itapoá - Santa Catarina, Brasil. Boletim do Instituto de Botânica 11: 1-79.

Labiak, P.H. \& Prado, J. 2003. Grammitidaceae (Pteridophyta) no Brasil com ênfase nos gêneros Ceradenia, Cochlidium e Grammitis. Hoehnea 30: 243-283.

Labiak, P.H. \& Prado, J. 2005a. As espécies de Lellingeria A.R.Sm. \& R.C. Moran 
(Grammitidaceae - Pteridophyta) do Brasil. Revista Brasileira de Botânica 28: 1-22.

Labiak, P.H. \& Prado, J. 2005b. As espécies de Melpomene e Micropolypodium (Grammitidaceae - Pteridophyta) no Brasil. Boletim de Botânica da Universidade de São Paulo 23: 51-69.

Labiak, P.H. \& Prado, J. 2005c. As espécies de Terpsichore A.R. Sm. e Zygophlebia L.E. Bishop (Grammitidaceae) do Brasil. Acta Botanica Brasilica 19: 867-887.

Labiak, P.H. \& Prado, J. 2008. New combinations in Serpocaulon and a provisional key for the Atlantic Rain Forest Species. American Fern Journal 98: 139-159.

Lellinger, D.B. 2002. A modern multilingual glossary for taxonomic pteridology. Pteridologia 3, American Fern Society, Washington, D.C.

Lorea-Hernández, F. 1995. Pleopeltis. In: R.C. Moran \& R. Riba (eds.). Psilotaceae a Salviniaceae. In: G. Davidse, M.S. Sousa \& S. Knapp (eds.). Flora Mesoamericana. Universidad Nacional Autónoma de México, Ciudad de México, v. 1, pp. 346-348.

Melhem, T.S., Giulietti, A.M., Forero, E., Barroso, G.M., Silvestre, M.S.F., Jung, S.L., Makino, H., Melo, M.M.R.F., Chiea, S.C., Wanderley, M.G.L., Kirizawa, M. \& Muniz, C. 1981. Planejamento para elaboração da "Flora Fanerogâmica da Reserva do Parque Estadual das Fontes do Ipiranga (São Paulo, Brasil)". Hoehnea 9: 63-74.

Milanez, A.I., Bicudo, C.E.M., Vital, D.M. \& Grandi, R.A.P. 1990. Criptógamos do Parque Estadual das Fontes do Ipiranga, São Paulo, SP: Planejamento. Hoehnea 17: 43-49.

Mickel, J.T. \& Smith, A.R. 2004. The Pteridophytes of Mexico. Mexico. Memoirs of the New York Botanical Garden 88: 1-1055.

Moran, R.C. 1995a. Polypodiaceae. In: R.C. Moran \& R. Riba (eds.). Psilotaceae a Salviniaceae. In: G. Davidse, M.S. Sousa \& S. Knapp (eds.). Flora Mesoamericana. Universidad Nacional Autónoma de México, Ciudad de México, v. 1, pp. 339-340.

Moran, R.C. 1995b. Phlebodium. In: R.C. Moran \& R. Riba (eds.). Psilotaceae a Salviniaceae. In: G. Davidse, M.S. Sousa \& S. Knapp (eds.). Flora Mesoamericana. Universidad Nacional Autónoma de México, Ciudad de México, v. 1, pp. 345-346.
Moran, R.C. \& Riba, R. 1995. Psilotaceae a Salviniaceae. In: G. Davidse, M.S. Sousa \& S. Knapp (eds.). Flora Mesoamericana. Universidad Nacional Autónoma de México, Ciudad de México, v. 1.

Moran, R.C., Prado, J. \& Labiak, P.H. 2009. Megalastrum (Dryopteridaceae) in Brazil, Paraguay, and Uruguay. American Fern Journal 99: 1-44.

Nóbrega, G.A. \& Prado, J. 2008. Pteridófitas da vegetação nativa do Jardim Botânico Municipal de Bauru, Estado de São Paulo, Brasil. Hoehnea 35: 7-55.

Parris, B.S. 1986. Grammitidaceae of Peninsular Malaysia and Singapore. Kew Bulletin 41: 491-517.

Pichi-Sermolli, R.E.G. 1996. Authors of scientific names in Pteridophyta. Royal Botanic Gardens, Kew.

Prado, J. 2004a. Criptógamos do Parque Estadual das Fontes do Ipiranga, São Paulo, SP. Pteridophyta: chave para as famílias; 2 . Blechnaceae. Hoehnea 31: 1-10.

Prado, J. 2004b. Criptógamos do Parque Estadual das Fontes do Ipiranga, São Paulo, SP. Pteridophyta: 6. Dicksoniaceae. Hoehnea 31: 239-242.

Prado, J. 2004c. Criptógamos do Parque Estadual das Fontes do Ipiranga, São Paulo, SP. Pteridophyta:14. Ophioglossaceae. Hoehnea 31: 171-174.

Prado, J.2004d. Criptógamos do Parque Estadual das Fontes do Ipiranga, São Paulo, SP. Pteridophyta:17. Pteridaceae. Hoehnea 31: 39-49.

Prado, J. 2004e. Criptógamos do Parque Estadual das Fontes do Ipiranga, São Paulo, SP. Pteridophyta: 8. Gleicheniaceae. Hoehnea 31: 33-37.

Prado, J. 2004f. Criptógamos do Parque Estadual das Fontes do Ipiranga, São Paulo, SP. Pteridophyta: 5. Dennstaedtiaceae. Hoehnea 31: 11-22.

Prado, J. 2004g. Criptógamos do Parque Estadual das Fontes do Ipiranga, São Paulo, SP. Pteridophyta: 15. Osmundaceae. Hoehnea 31: 93-96.

Prado, J. 2006a. Criptógamos do Parque Estadual das Fontes do Ipiranga, São Paulo, SP. Pteridophyta: 18. Salviniaceae. Hoehnea 33: 107-110.

Prado, J. 2006b. Criptógamos do Parque Estadual das Fontes do Ipiranga, São Paulo, SP. Pteridophyta:12. Lophosoriaceae. Hoehnea 33: 123-126.

Prado, J. \& Hirai, R.Y. 2008. Criptógamos do Parque Estadual das Fontes do Ipiranga, São Paulo, SP. Pteridophyta: 13. Lycopodiaceae e 20. Selaginellaceae. Hoehnea 35: 543-552. 
Ranker, T.A., Smith, A.R., Parris, B.S., Geiger, J.M.O., Haufler, C.H., Straub, S.C.K. \& Schneider, H. 2004. Phylogeny and evolution of grammitid ferns (Grammitidaceae): a case of rampant morphological homoplasy. Taxon 53: 415-428.

Rolim, L.B. \& Salino, A. 2008. Polypodiaceae Bercht \& J. Presl (Polypodiopsida) no Parque Estadual do Itacolomi, MG, Brasil. Lundiana 9: 83-106.

Salino, A., Almeida, T.E., Smith, A.R., Gómez, A.N., Kreier, H.P. \& Schneider, H. 2008. A new species of Microgramma (Polypodiaceae) from Brazil and recircumscription of the genus based on phylogenetic evidence. Systematic Botany 33: 630-635.

Schneider, H., Smith, A.R., Cranfill, R., Hildebrand, T.J., Haufler, C.H. \& Ranker, T.A. 2004. Unraveling the phylogeny of polygrammoid ferns (Polypodiaceae and Grammitidaceae): exploring aspects of the diversification of epiphytic plants. Molecular phylogenetics and evolution 31: 1041-1063.

Smith, A.R. 1992. A review of the fern genus Micropolypodium (Grammitidaceae). Novon 2: 419-425.
Smith, A.R. 1993. Terpsichore, a new genus of Grammitidaceae (Pteridophyta). Novon 3: 478489.

Smith, A.R. 1995. Grammitidaceae. In: R.C. Moran \& R. Riba (eds.). Psilotaceae a Salviniaceae. In: G. Davidse, M.S. Sousa \& S. Knapp (eds.). Flora Mesoamericana. Universidad Nacional Autónoma de México, Ciudad de México, v. 1, pp. 366-367.

Smith, A.R., Kreier, H.P., Haufler, C.H., Ranker, T.A. \& Schneider, H. 2006a. Serpocaulon (Polypodiaceae), a new genus segregated from Polypodium. Taxon 55: 919-930.

Smith, A.R., Pryer, K.M., Schuettpelz, E., Korall, P., Schneider, H. \& Wolf, P.G. 2006b. A classification for extant ferns. Taxon 55: 705-731.

Smith, A.R., Pryer, K.M., Schuettpelz, E., Korall, P., Schneider, H. \& Wolf, P.G. 2008. Fern classification. In: T.A. Ranker \& C.H. Haufler (eds.). Biology and evolution of ferns and lycophytes. Cambridge University Press, Cambridge, pp. 417-467.

Tryon, R.M. \& Tryon, A.F. 1982. Ferns and allied plants, with special reference to tropical America. Springer-Verlag, New York. 